\title{
Best Interests of the Child in the Norwegian Constitution
}

\author{
Kirsten Sandberg
}

The best interests of the child have been a guiding principle in the laws on children and parents and on child welfare in Norway since the 1950 os and have also been included in a few other areas of the law. Since the incorporation, in 2003, of the United Nations Convention on the Rights of the Child (CRC) into Norwegian legislation through the Human Rights Act, ${ }^{1}$ the convention has the status of statutory law ranking above ordinary legislation. The topic of this chapter is whether including the best interests of the child in the Constitution, in 2014, has made a difference.

The second subsection of section 104 on children's rights states as follows:

In actions and decisions affecting children, the best interests of the child shall be a primary consideration. ${ }^{2}$

The Law Commission preparing the human rights provisions in the Norwegian Constitution deliberately chose a wording that would in a simple and easily understandable way express the state of the law at that time. It added that the wording resembles the formulations used in article 3 of the CRC and the EU Charter of Fundamental Rights, thus making it possible to use jurisprudence related to those provisions in the interpretation. ${ }^{3}$ The provision remained the same throughout the further preparation of the human rights chapter in the Constitution, with the exception of the term 'actions' being added, see 2.1

1 Act relating to the strengthening of the status of human rights in Norwegian law (Human Rights Act) of 21 May 1999 No. 30 (menneskerettsloven) <https://app.uio.no/ub/ujur/ oversatte-lover/data/lov-19990521-o3o-eng.pdf > accessed 2 April 2019.

2 Author's translation.

3 Dokument 16 (2011-2012) Rapport til Stortingets presidentskap fra Menneskerettighetsutvalget om menneskerettigheter i Grunnloven (9 December 2011) 32.5.4, 192.

(C) KIRSTEN SANDBERG, 2020 | DOI:10.1163/9789004382817_009

This is an open access chapter distributed under the terms of the CC-BY-NC 4.0 kicensese Sandberg - 9789004382817 
below. It seems to be generally accepted that the intention of the parliament is relevant to the interpreation of the Constitution. ${ }^{4}$

For the sake of comparison, I include the two provisions that served as models:

\section{CRC article 3(1):}

1. In all actions concerning children, whether undertaken by public or private social welfare institutions, courts of law, administrative authorities or legislative bodies, the best interests of the child shall be a primary consideration.

\section{EU charter article 24(2):}

2. In all actions relating to children, whether taken by public authorities or private institutions, the child's best interests must be a primary consideration.

While referring specifically to best interests in the 1981 Children and Parents Act section 48, the Law Commission added that the principle reaches beyond decisions on parental responsibility, residence and contact. The aim of including it in the constitution was to make it generally visible. ${ }^{5}$

In the following, I will first present the constitutional provision on best interests with reference to the reasoning given in the preparatory works in more depth. Subsequently, I discuss the interpretation of the provision through a couple of central Supreme Court judgments. The following subchapters consider the possible impact of the constitutionalisation of best interests on case law and preparation of legislation. Finally, in the concluding remarks, I will comment on the development so far, the importance of section 104(2) for other actions than case law and legislation, and the prospects of an increased impact of children's best interests through their constitutionalisation.

\section{Certain Issues in the Text and Its Preparatory Works}

\subsection{Introduction}

This section will focus on certain issues that arise from the text of section 104(2) or the explanation given in the preparatory works. The main document

4 Arnfinn Bårdsen, 'Norges Høyesterett og «barnets beste» som konvensjonsforpliktelse og grunnlovsnorm' in Magnus Matningsdal, Jens Edvin A Skoghøy and Toril Marie Øie (eds), Rettsavklaring og rettsutvikling: Festskrift til Tore Schei (Universitetsforlaget 2016) 243-268, 251.

5 Dokument 16 (n 3) 32.5.4, 192. 
in preparation of the new chapter is the Law Commission's report mentioned above. Additionally, I will refer to the report of the Parliament Standing Committee on Scrutiny and Constitutional Affairs which is the internal body preparing the case for the debate in Parliament. The preparatory works are relevant to the interpretation and normally given some weight. The issues dealt with below are the scope of the provision, the link between best interests and the right of the child to be heard, the weight of the child's best interests, and finally the significance of section 104(2) as envisaged by the Law Commission.

\subsection{Scope of the Provision}

While the two model provisions only mention 'actions', the Norwegian one adds 'decisions'. In the Norwegian legal context where (physical) actions are often discussed as being contrary to decisions it may be useful for pedagogical purposes that decisions are specifically mentioned to avoid any misunderstanding.

Like CRC article 3, the constitutional provision uses 'children' in the plural in the first part of the sentence and 'the child' in the second part. In its rather sparse comments the Commission seems to have individual decisions in mind, but does not explicitly comment on whether the provision is meant for groups of children as well. The question is relevant to legislative processes and other general decisionmaking, such as local decisions on where to place a school or on public transportation, or the environment for that matter. It is generally acknowledged that, under CRC article 3 , the best interests of children or a group of children shall be taken into account as a primary consideration in legislation and other general actions concerning them. ${ }^{6}$ The wording of section 104(2) does not indicate that it is limited to individual decisions, and when nothing to the contrary is explicitly said in the preparatory works, it should be understood to include general decisions. This is important for all kinds of general decisions at the local, regional or central level. For most decisionmaking the obligation already follows from the CRC being incorporated in the Human Rights Act. Including it in the Constitution, however, makes it an obligation which is binding even on Parliament. So for all laws affecting children their best interests need to be considered in developing and adopting formally enacted legislation.

The required relationship between the action in question and the child is somewhat complicated due to different terms used in English and Norwegian

6 UN Committee on the Rights of the Child, General Comment No. 14 on the right of the child to have his or her best interests taken as a primary consideration (art. 3, para. 1) (29 May 2013) $\mathrm{CRC} / \mathrm{C} / \mathrm{GC} / 14$, paras 19, 23 and 99. 
in different contexts. Irrespective of this, the Law Commission explains that the Norwegian term used in section 104(2) on best interests (berører) is a wider term than the one used in section 104(1) on children's right to be heard (gjelder). Their explanation is that children do not have the right to participate in all cases affecting them. Consequently, under the Constitution the decision-maker may not have to hear the child in all instances where he or she has to undertake a best interests assessment. In a way this makes sense. For example, Norwegian judges are gradually realising that they should take the best interests of a child into consideration when sentencing its parents for a crime, at least if the child resides with that parent and imprisonment is a possible outcome. ${ }^{7}$ In that context judges have questioned whether they should actually hear the child in the criminal case, indicating that this does not seem natural, which is in my view understandable. On the other hand, according to the CRC, the child has the right to be heard whenever a decision 'affects' them, which sentencing a parent to prison would certainly do. This question of interpretation is more closely linked with the right of the child to be heard than with best interests, but it certainly has a bearing both on the willingness of decisionmakers to take the child's best interests into account and on the contents of those interests.

The Norwegian Constitution does not indicate whose decisions or other actions are covered by this obligation, as opposed to its models. The preparatory works just briefly mention that the provision covers decisions made by public authorities and private persons, including legal persons. ${ }^{8}$ In the EU charter, the reference is quite simply made to public authorities and private institutions, whereas the $\mathrm{CRC}$ has a longer list but covering more or less the same actors. Probably the reason for omitting a reference to the actors in the text itself is that the Consitutional provisions were supposed to state the universal human rights principles without too many specificities. ${ }^{9}$

Since the Constitution does not specify any duty-bearers, the obligation must be understood to rest on anyone dealing with children. This would include parents and other individuals who are not covered by the international provisions. It remains to be seen whether this will make any difference in practice, particularly for parents and other individuals. To place criminal liability on anyone for an action that is not in a child's best interests, based on the Constitution alone, is out of the question. It would need a specific provision in statute, due to the requirement of legality (Constitution section 96). As for civil

7 Discussions at training courses for lawyers where the author has been present.

8 The Norwegian term used is 'private', which includes legal persons such as organisations, institutions and companies.

9 Mandate of the Human Rights Commission, see Dokument 16 (n 3) 2.2. 
cases between individuals, parental conflicts are the most practical ones, and the best interests of the child are already the guiding principle for these under the Children and Parents Act. Should a conflict arise between, for example, a mother and a grandmother regarding residence of or contact with a child the grandmother does not have standing before the courts under the Children and Parents Act today, unless one of the parents is dead, see sections 46 and 63. Being an overarching rule, the constitutional provision might possibly lead to a different approach to the grandmother's claim. The court, being bound by the Constitution, may perhaps have to deviate from the Act and consider what solution is all in all in the child's best interests. Vis-à-vis the mother in this case it may play a role that the Constitution does not limit the obligation to respect the child's best interests to certain actors. The issue is closely related to the potential right of the child and the grandparent to respect for their family life with each other under section 102, which is not up for discussion here.

The CRC has an additional provision on best interests in relation to parents. Recognising the primary responsibility of parents for the upbringing and development of the child, article 18(1) adds: " $[t]$ he best interests of the child will be their basic concern'. While thus stating what is expected of parents, the Convention cannot place direct obligations on them. Like all human rights conventions, it can only commit states through their ratification, whereas the Constitution is binding on everybody.

\subsection{Link with the Child's Right to Be Heard}

In line with CRC article 3(1) the Constitution, section 104(2), does not specify the contents of the child's best interests, nor do the preparatory works attempt to do so. Still the Law Commission mentions that it is a natural extension of the right of the child to be heard with weight attached to the child's views. At the same time, the best interests of the child shall be taken into account, whether they concur with the child's views or not. ${ }^{10}$

From this statement a few points may be deducted. First, the views of the child form an element in the best interests assessment. Under section 104(1), children have a right to be heard in issues concerning them, and their views are to be given weight in accordance with their age and development.11 Consequently, they have a constitutional right to be heard in relation to most ${ }^{12}$ best interests assessments, and their views are to be considered in assessing the

\footnotetext{
$10 \quad$ Dokument 16 (n 3 ) 32.5.4.

11 See Anna Nylund, 'Children's Right to Participate in Decision-Making in Norway' in Trude Haugli and others (eds), Children's Constitutional Rights in the Nordic Countries (Brill 2019). 
child's best interests. This also follows from CRC articles 12 and 3 and General Comments No. 12 and $14 .{ }^{13}$ There is a slight difference as the Constitution only says that the views of the child should be given 'weight', not 'due weight'. Although the formulation in the Constitution thus appears to be weaker, it may not make a difference in practice as long as both provisions add 'in accordance with age and maturity'. One may argue that the requirement of 'due' is implicit.

Secondly, it follows from what has just been said that the views of the child are not necessarily decisive. Depending on the circumstances, the child's best interests may all in all indicate a different solution than the one the child would have liked to see. ${ }^{14}$ This is in line with the CRC and its interpretation, where the child's views form one of the elements in the best interests assessment, albeit an important one. ${ }^{15}$

Thirdly, the previous point implies that the responsibility for determining the child's best interests does not rest with the child. It lies with the adult decisionmaker, who cannot leave the decision to the child. Following the child's views should never be an easy way out for the adult decisionmaker who has to assess and determine the best interests of the child in a holistic way as mentioned above. ${ }^{16}$

All of these points imply that the best interests assessment has to be based on the specific circumstances of the individual child. ${ }^{17}$ This is perhaps the most essential aspect of the concept of best interests and follows from the wording itself, 'the best interests of the child'. The preparatory works of the Constitution do not say this explicitly, but it seems to be taken for granted. As the purpose of including human rights in the Norwegian Constitution was to ensure the universal principles, not the details, ${ }^{18}$ section 104(2) does not list the elements in the best interests assessment, nor do the preparatory works.

What I have said here is directly about individual decisions, but it is also relevant to decisions or actions of a general nature. Then it is the views of children in general or the group of children concerned that have to be considered in determining their best interests. ${ }^{19}$

13 UN Committee on the Rights of the Child, General Comment No. 12: The right of the child to be heard (20 July 2009) CRC/C/GC/12, General Comment No. 14 (n 6).

14 Dokument 16 (n 3$)$ 32.5.4.

15 Art $12(1)$ 'due weight', General Comment No. 14 paras (n 6) $52-53,83$.

16 Kristin Skjørten and Kirsten Sandberg, 'Children's Participation in Family Law Proceedings' in Malcolm Langford, Marit Skivenes and Karl Harald Søvig (eds), Children's Rights in Norway: An implementation Paradox? (Universitetsforlaget 2019), eg 4.2.2 at n 40, referring to LG-2006-62064 (Court of Appeal).

17 General Comment No. 14 (n 6) paras 24, 32.

18 Dokument 15 (n 3 ) 2.2 (the Commission's mandate).

19 General Comment No. 12 (n 13) paras 73, 87; General Comment No. 14 (n 6) para $5^{2}$ 'child or children'. 


\section{$2.4 \quad$ Weight of Best Interests}

A decision or other action may not only concern children, but other individuals, groups or interests as well. Once the best interests of the child or children have been assessed and determined, they must be balanced with those other rights or interests. According to the Commission, the weight of the child's best interests in a decision will vary according to how strongly the child is affected and how serious the decision is for the child. In cases concerning parental responsibility, residence and contact, the child's interests should carry great weight. In other cases, where the child is less affected, other factors may be given weight as well. Consequently, the Commission says, the best interests of the child principle will imply a proportionality consideration. ${ }^{20}$ The Parliament Standing Committee in its subsequent report repeated that the weight of the child's best interests must be viewed in relation to how strongly the child is affected and how serious the decision is for the child.

General Comment no. 14 does not describe article 3(1) as a proportionality principle, but it does state the following:

[S]ince article 3, paragraph 1 , covers a wide range of situations, the Committee recognizes the need for a degree of flexibility in its application. ${ }^{21}$

It adds that the word 'primary' requires the following:

[A] willingness to give priority to those interests in all circumstances, but especially when an action has an undeniable impact on the children concerned. ${ }^{22}$

Thus, the Committee on the Rights of the Child acknowledges that the weight is to a certain extent relative. There does not seem to be any intended difference between this and the Law Commission's comment on proportionality.

The Law Commission also states that the child's best interests shall be taken into consideration, but not necessarily be decisive. ${ }^{23}$ This statement was related to two possible wordings that they discussed. The one they chose contained the words 'primary consideration', whereas the other one only said that the best interests of the child should be considered. Certainly the word 'primary' distinguishes the two options from one another and makes the wording of the

\footnotetext{
$20 \quad$ Dokument 16 (n 3 ) 32.5.4.

21 General Comment No. 14 (n 6) para 39.

22 General Comment No. 14 (n 6) para 40.

23 Dokument 16 (n 3 ) 32.5.4.
} 
present text stronger, meaning that the best interests are not just one out of a number of considerations, even if the Law Commission did not comment explicitly on this.

\subsection{Significance of the Provision}

While emphasising the strong political and symbolic significance of a constitutional provision on children's rights, the Law Commission added that it could also have a legal impact, depending on the areas covered by a constitutional provision and how they would be delimitated. First and foremost it would be a factor in the interpretation of other pieces of legislation, implying in many instances that legislation be interpreted so as to give the 'best solution' for children. The constitutional provision might also be used as a barrier against adopting legislation that disregards children's need of favourable conditions for their upbringing and protection against abuse. ${ }^{24}$

As a factor in the interpretation of laws, seeking the best solution for the child must be understood as a reference to the child's best interests. As Stang points out, this obligation already followed from the CRC article 3(1), as incorporated in Norwegian legislation through the Human Rights Act, with priority over ordinary legislation. ${ }^{25}$ Best interests as a barrier for the legislator may arguably have followed already from the ratification of the CRC, see Stang. ${ }^{26}$ However, in guiding the interpretation of other Acts a constitutional provision is stronger than a convention incoporated through ordinary statute. It also forms by far a stronger barrier than a Convention, whether incorporated or only ratified. Should any piece of legislation not take children's best interests into account, it would undoubtedly be easier for the courts to set it aside based on the Constitution than on the CRC.

As expressed by Sinding Aasen, even if the provision does not really change Norwegian law, constitutionalisation has added a particular weight to best interests. ${ }^{27}$ She adds that section 104 clearly expresses that children's needs and interests shall enjoy a strong legal protection in Norway.

The Law Commission mentioned that the best interests principle was already included in several pieces of specific legislation in addition to the

24 Dokument 16 (n 3 ) 32.5.1.

25 Elisabeth Gording Stang, 'Grunnloven § 104: En styrking av barns rettsvern?' in Geir Kjell Andersland (ed), De Castbergske barnelover 1915-2015 (Universitetsforlaget 2015) 104-105.

26 Stang (n 25) 105.

27 Henriette Sinding Aasen, 'Grunnloven § 104 og barnets beste: Høyesterett viser vei' (2015) 3 Tidsskrift for familierett, arverett og barnevernrettslige spørsmål 197-201, 197. 
Children Act, such as the Child Protection Act, the Immigration Act and in its universal form in the CRC article 3(1). Interestingly, the Commission added that including the principle in the Constitution would make it generally visible, without altering the legal situation. ${ }^{28}$ The latter seems to be in contrast to what is cited from the Commission's report above, about the possible legal impact of a provision. That statement, however, concerned a provision on children's rights in general, whereas the limitation to visibility is directed specifically at the part on best interests and thus is more relevant in this context.

An interesting issue before Norwegian courts has been whether article 3 is justiciable in and of itself, without being connected to some other claim, for compensation, for an administrative act to be set aside, etc. The Supreme Court of Norway, in 2012, decided that article 3 is not justiciable as such, because it does not give the child a legal claim. ${ }^{29}$ The majority did not distinguish between the substantive and procedural implications of article 3(1). ${ }^{30}$ In his dissenting opinion, Justice Bårdsen argued that article 3(1) indeed places obligations on the States and gives the child an individual right. The fact that its wording is vague and general is not unusual in a human rights context. He noted that when the CRC was incorporated into the Human Rights Act, it was presumed to become directly applicable. Even if this might not fully apply to some of the economic, social and cultural rights, such limitations are not relevant to article 3(1). He found a violation of article 3(1) in that it was unclear in the present case whether the norm of making best interests 'a primary consideration' had been applied in a correct manner. Thus, the way I read his opinion, he spoke about the substantive aspect of article $3(1) \cdot{ }^{31}$

In a subsequent article, Bårdsen argues that section 104(2) sheds new light on this issue, and that the solution chosen by the Supreme Court regarding article 3(1) cannot automatically be transferred to the new constitutional rights. ${ }^{32} \mathrm{He}$ does not elaborate on this point of view.

The possible signifance of the provision will be further discussed in the following.

28 Dokument 16 (n 3) 32.5.4.

29 Rt 2012 p 2039, para 101.

30 See Kirsten Sandberg, 'Barnets beste som rettighet' in Ingunn Ikdahl and Vibeke Blaker Strand (eds), Rettigheter i velferdsstaten: Begreper, trender, teorier (Gyldendal Akademisk 2015) chapter $3,57-83$ for a discussion of art. 3 (1) as containing various elements of rights.

31 Rt 2012 p 2039, paras 116-130.

$3^{2} \quad$ Bårdsen (n 4) 267. 


\subsection{General Aspects}

An important question is whether international sources of interpretation of CRC article 3(1) can be used in the interpretation of section 104. According to the statement by the Law Commission mentioned above, the resemblance between the constitutional provision and article 3 makes it possible to use jurisprudence under the latter to interpret section 104(2). It even states that such jurisprudence will make a useful contribution to its interpretation. ${ }^{33}$ For a general discussion of the use of international sources in the interpretation of section 104, see chapter 3 above. Below I will specifically discuss the use of General Comment No. 14 in relation to best interests.

\subsection{Best Interests and the Maria Judgement}

General Comment No. 14 on the best interests of the child had already been adopted before the adoption of the human rights provisions in the Constitution in 2014. Thus it does not fall into the category of later jurisprudence of a more dubious position in relation to the Constitution. According to the judgment in the so-called Maria case, Rt. 2015 p. 93, the general comment is a natural starting point for the interpretation of article 3(1) and thus of section 104(2). The Court (Justice Bårdsen) in its reasoning refers to the statement by the Law Commission on the use of international jurisprudence in the interpretation of this provision and applies General Comment No. 14 in its discussion of the balancing of best interests with other interests. With reference to the Committee on the Rights of the Child, it states that the best interests of the child shall carry great weight and not just be one of several considerations: They are to form the starting point, be given particular attention and be in the forefront. ${ }^{34}$

In relation to this judgment, Stang notes as positive that the Supreme Court used section 104 as a basis for conducting a more in-depth examination of the child's best interests assessment undertaken by the administrative authorities than in previous case law. Furthermore, the Supreme Court confirmed that the best interests principle gives the child an individual right to have its interests taken into account as a primary consideration. ${ }^{35}$ In her view, case law may indicate that including children's best interests in the Constitution has contributed to strengthening the legal protection of children, particularly in areas

\footnotetext{
33 Dokument 16 (n 3 ) 32.5.4.

34 Rt 2015 p 93 (the Maria case), 65 .

35 Stang (n 25) 135 .
} 
where best interests do not already have such a firm position, for example, in immigration cases. ${ }^{36}$

Aasen sees the judgment as expressing that the Supreme Court considers international rules to be very important, but not as a replacement of a national legal system with the Constitution and the Supreme Court as guarantors of the rights of the individual. She adds that the clear anchoring of the judgment in section 104 brings forebodings of an increased significance of the Constitution as a source of law. ${ }^{37}$

I agree with these authors in their views on the promising aspects of that judgment as such. Still, their comments were written shortly after the judgment was delivered. Already in the same year the Supreme Court in the plenary took a much less active position to the application of best interests in an immgration case, which I will now turn to.

\subsection{Plenary Judgment and General Comment No. 14}

\subsubsection{Starting Point of the Interpretation}

In a later plenary judgment, Rt. 2015 p. 1388 (immigration, internal flight), section 104 was not seen to be applicable as it had not been adopted at the time of the administrative decision which was under review. The majority, however, could not see that section 104 being applied to the case would have given the children any stronger position than they had before. ${ }^{38}$ As noted by Bendiksen and Haugli, the statement tones down the significance of section $104^{39}$ with regard to best interests. But being an obiter dictum, a statement without relevance to the case in question, it does not carry the same weight as it would otherwise have done.

In this case, the Supreme Court is less positive than in the previous judgment to using the Committee's general comments in the interpretation, and General Comment No. 14 on best interests was particularly discussed. Even if the Court's discussion in this respect is not about the constitutional provision, the weight of general comments are of interest not only in interpreting the Convention but also the constitutional provision modelled on it. After presenting the various opinions, I will return to the possible significance of the case for the question we deal with in this book: Does constitutionalisation of children's rights and, more specifically, the best interests of the child, matter?

$36 \quad$ Stang (n 25) 136-37.

37 Aasen (n 27).

$38 \quad$ Rt 2015 p 1388.

39 Lena Bendiksen and Trude Haugli, Sentrale emneribarneretten (3rd ed, Universitetsforlaget 2018) 56. 
Instead of considering general comments as a natural starting point of the interpretation, the majority states that they are not legally binding. It continues by saying that the weight of a general comment depends on how clearly it expresses the monitoring body's understanding of the parties' obligations under the convention, in particular, whether the statement in question is an interpretative statement or rather a recommendation of best practice. Additionally a statement's relevance to the facts and law of that particular case should be considered. ${ }^{40}$ So in spite of its more sceptical attitude even the majority considers general comments to be relevant sources of interpretation.

The minority, in discussing General Comment No. 14, states that although the Committee's general comments are not binding, they are used in the interpretation by, among others, the European Court of Human Rights (ECtHR) and the UK Supreme Court. General comments should carry weight in the interpretation because they are based on the overall experience of the Committee on the Rights of the Child and the special role it has been given as the primary monitoring body in international law under the CRC. ${ }^{41}$

\subsubsection{Justification of the Contents and Weight of Best Interests}

The difference in approach and attitude appears most clearly in relation to what is required of the justification of the administrative decision. The Court's majority accepts that in the Immigration Board's consideration of humanitarian grounds for granting a residence permit, the best interests of the child were not explicitly discussed, as long as it appeared from the interpretation of the decision that best interests had been a primary consideration. ${ }^{42}$

One of the dissenting opinions (supported by 7 out of the 18 justices) is interesting in this respect:

It has to appear from the decision that the best interests of the child have been a primary consideration. Thus, the child's interests must be identified and described, and an assessment must be made of those aspects of the child's situation that may be relevant to the case. ${ }^{43}$

Instead of leaving it to the reader to interpret the administrative decision to find out whether the child's best interests have been determined in a satisfactory way, it places more specific requirements on the explicit justification of

\footnotetext{
$40 \quad$ Rt 2015 p 1388, paras 151-52.

41 Rt 2015 p 1388, paras 271-72.

42 Rt 2015 p 1388, para 192.

43 Rt 2015 p 1388, para 273, Justice Bergsjø.
} 
the decision. This is in line with General Comment No. 14, which requests the following:

the justification of a decision must show that the right has been explicitly taken into account. In this regard, States parties shall explain how the right has been respected in the decision, that is, what has been considered to be in the child's best interests; what criteria it is based on; ... ${ }^{44}$

Regarding the weight of best interests, General Comment No. 14 says that 'States parties shall explain ... how the child's interests have been weighed against other considerations'. ${ }^{45}$ According to the Court's majority, it is hard to tell whether this is the Committee's view of how article 3 legally is to be understood or just an aim. ${ }^{46}$ In my view, there is no reason to doubt that this is a legal interpretation by the Committee. It is formulated in the language of obligations, not more vaguely as an aim. Also, this interpretation of article 3(1) should be uncontroversial. If the courts are to monitor whether, in an administrative decision, best interests have been balanced with other considerations in a satisfactory way, then the balancing exercise needs somehow to be described in the decision.

The minority, on the other hand, finds good guidance in General Comment No. 14 in considering what article 3(1) requires of the justification of a decision and accepts the Committee's words as a legal requirement. ${ }^{47}$ The justification of a decision is seen to be important not only for the sake of an effective judicial review, but also to structure the process of decision-making and ensure that the relevant considerations have been taken into account. In short, the justification should both ensure and demonstrate that the best interests of the child have been a primary consideration..$^{48}$ f find the discussion of these issues clarifying and useful.

\subsection{Some Concluding Remarks on the Interpretation Issues}

The majority in the plenary judgment has an overall sceptical attitude to the interpretative value of the Committee's general comments but does not reject them as a possible argument in the interpretation. In its interpretation of the Committee's statements, however, the majority seems to be influenced by its own basic attitude, demonstrated by what is in my view an unreasonable interpretation of General Comment No. 14 concerning the justification regarding

\footnotetext{
44 General comment no. 14 (n 6) para 6(c).

45 Ibid.

$46 \quad$ Rt 2015 p 1388 , para 185.

$47 \quad$ Rt 2015 p 1388 , para 272.

48 Rt 2015 p 1388, para 274.
} 
best interests under article 3(1). A topical question is whether this reserved attitude towards General Comment No. 14 and the lenient expectations of the immigration authorities in justifying their decisions also express a reservation with regard to the weight of best interests. This would actually imply a reservation towards the Constitution section 104(2) as well, through the above mentioned statement which downplays its possible influence.

The encouraging aspect of the latter judgment is the fact that as many as 7 out of 18 justices did not agree with the majority neither on the value of general comments in the interpretation nor on the justification of the best interests consideration. It is a timely question whether the inclusion of best interests in the Constitution could influence the way these issues are considered and bring more Justices to recognise the importance of administrative authorities making proper best interests considerations, including the balancing exercises. As the effects of the constitutionalisation were not properly discussed in the plenary judgment, the majority's brief statement in this regard carries little weight. Arguably, the inclusion of best interests in the Constitution could and should influence the way they are dealt with both by administrative authorities and the courts. By using section 104(2) to expect more of the administrative authorities in the justification of their decisions, the courts could enhance the best interests of the child as a primary consideration. They might well require more of the way the best interests assessment and determination are described, as well as the explanation of how the best interests of the child are balanced with other interests in the case. In that way, the courts could demonstrate the importance of rights being included in the Constitution.

Impact on Case Law

\subsection{Introduction}

In discussing the possibility of a stronger position for the best interests of the child following their inclusion in the Consitution, it is not so interesting to try to predict the behaviour of Supreme Court Justices. I will rather try to see if there is anything in the constitutionalisation itself that could arguably lead to a strengthening of the position of the child's best interests in a legal sense. With that in mind, I have looked at recent Supreme Court practice where section 104 has been mentioned. Most of the decisions are short rulings where the provision is either just argued by the parties or briefly mentioned by the Court. Others deal with different parts of section 104 such as the right to be heard. Below I present a few decisions that in my view may indicate something about the value of best interests being included in the Consitution. 


\subsection{Child Protection-the Jakob Case}

In a judgment from 2017 in a child protection case, the question was whether contact between parents and child should be denied because the parents had exposed their baby boy to serious violence before he was six weeks old (called the Jakob judgment). ${ }^{49}$ At that age it had been discovered that the baby had 19 rib fractures, and the parents were later held criminally liable, the father for causing the injuries and the mother for not providing medical assistance. The Supreme Court decided in favour of supervised contact once a year for one hour. On the constitutional issues the Court states that the right to family life under the Constitution section 102 has to be seen in connection with section 104 and CRC article 3(1). As the two provisions are complementary, the child's interests carry great weight in the consideration of proportionality under section 102, it said. The Court also discussed practice from the ECtHR under article $8,{ }^{50}$ including more recent judgments than the adoption of the Constitutional human rights provisions in 2014, implying that it does not limit its use of such practice to earlier decisions.

The Supreme Court focuses on the requirement of the ECtHR that a measure not in line with the aim of reunification of child and parents may only be applied in 'exceptional circumstances'. Yet, the Supreme Court upholds its own interpretation of this criterion, that contact may only be denied for 'special and strong reasons'. In my view there may be a certain difference between this and the criterion as formulated by the ECtHR. The term exceptional circumstances leads us to look at the child's situation as a whole, taking past and present circumstances into consideration, whereas special and strong reasons may imply that something is needed in addition to the situation being exceptional - at least in the way the Supreme Court applies the criterion in this case. The abuse of the child in my view undoubtedly forms exceptional circumstances. Yet it is almost invisible in the Court's reasoning, which only occupies itself with possible reasons for denying contact, none of which the Supreme Court finds to be special and strong enough. The problem may lie primarily in the application of the criterion in this case, but it may also be a consequence of transforming the ECtHR requirement into something with a slightly dfferent connotation.

Due to the requirement of special and strong reasons it seems that the biological principle in its abstract sense - as a value for the child - overrides the other, more concrete interests of the child. With the Court's reasoning that

\footnotetext{
49 HR-2017-2015-A.

$5^{\circ} \quad$ European Convention on Human Rights, Article 8.
} 
contact is of possible advantage for the child in the long run, irrespective of the particular circumstances of the case, great weight is in reality attached to biology. Even though the biological argument may deserve a place among the elements in a best interests assessment, in my view, it was given too much attention in this case at the cost of all the other elements that should be taken into account, which might all in all have been considered as exceptional circumstances justifying the family ties being severed. ${ }^{51}$

\subsection{Other Child Protection Cases}

In the judgment in HR-2016-2262-A concerning whether a three-year-old child should remain in public care, the Supreme Court found that the conditions in the Norwegian Child Protection Act for non-return of the child were fulfilled, and subsequently considered whether human rights might lead to a different result. Referring to the best interests of the child being explicitly mentioned in section 104 and CRC article 3(1) but not in the European Convention on Human Rights (ECHR) article 8, the Court discussed the practice of the ECtHR in this regard. The mother had returned to South America while the child was in a Norwegian foster home, and the child did not yet speak the mother's language. In light of the possibilities of contact in this situation being severely limited, the Court found that retaining the boy in public care would require very strong reasons. Still, it was in the best interests of the child that the placement be continued. Moving to his mother in South America would be a very exceptional strain on the boy and imply a great risk of serious harmful effects. In this situation other considerations, such as the mother's interests and the child's need for contact with his biological mother, her family and her culture and language would have to be set aside. The Supreme Court in this case seems to have undertaken a proper individual best interests assessment, looking into what was in the best interests of the child all things considered.

The judgment in Rt. 2015 p. 110 concerns adoption in a child protection case. The Supreme Court referred to the fact that adoption is a far-reaching decision for which CRC article 21 requires that the best interests of the child shall be not only a primary, but the paramount consideration. On the other hand, the Court said the parents' interests have to yield where decisive circumstances on the part of the child speak in favour of adoption. In this regard, the Court referred to the Constitution section 104(2), CRC article 3(1) and the ECtHR judgment

$5^{1}$ See, also, Markus Jerkø, 'Skal ikke «barnets beste» leses bokstavelig?: En kritikk av HR2017-2015-A 'Jakob-saken” (2018) 57(2) Lov og Rett 112. 
Aune v. Norway $(2010)^{52}$ where no violation was found. The ECtHR stated that an adoption could only be considered necessary under art. 8 if it was motivated by 'an overriding requirement pertaining to the child's best interests. ${ }^{53}$ Since the ECtHR accepted the reasoning in the Norwegian Supreme Court Aune judgment, the expression used there - particularly weighty reasons being required for an adoption to take place - was considered by the Supreme Court in the 2015 decision to express the same norm as the one quoted from the ECtHR. ${ }^{54}$ The case is pending before the ECtHR at the moment (1/9/2018, Pedersen). I have included it because the reasoning of the Supreme Court is of interest anyway.

\subsection{Cases from Other Areas}

In a case regarding compensation for manslaughter committed by a child of 15.5 years, the child (represented by his guardians) had asserted that since under section 104 and the CRC article 3(1) the best interests of the child shall be a primary consideration, he should be exempted from liability for compensation to the relatives of the two victims. The Supreme Court interpreted the 1969 Compensation Act ${ }^{55}$ in the light of these provisions, pointing to the fact that the Act and its preparatory works were written at a time when children's rights were less prominent. Still, the Court said, the child's best interests are not necessarily decisive. To what extent they override other interests, depends on an individual assessment and balancing of the different relevant considerations (51). The Court discussed CRC article 40 on children in conflict with the law and the importance of rehabilitation, but found that General Comment No. 10 on children in conflict with the law did not shed any light on the issue of compensation. The Court added that the considerations in the general comment had been duly taken care of in deciding the prison sentence in this case.

Summing up, the Court found that the Compensation Act section 1-1 on the liability of children is formulated in such a way as to give the flexilibility necessary to comply with the obligations towards children under the Constitution and the CRC. According to section 1-1, children under the age of 18 years are under the obligation to pay compensation for harm they have caused intentionally or negligently, provided that it is reasonable with regard to the child's age, development, behaviour, economy and other circumstances. The Court said that both in relation to the basic requirement for imposing liability on a

\footnotetext{
52 Aune v Norway App no 52502/o7 (ECtHR, 28 October 2010).

53 Aune v Norway (n 52) para 66.

54 Rt 2015 p 110 para 46.

55 Act relating to compensation in certain circumstances of 13 June 1969 No. 26 (skadeserstatningsloven). The English translation is in printed version only.
} 
child and in determining the amount, the best interests of the child shall be a primary consideration. The aims of rehabilitation and resocialisation of the child have to be taking into account in the consideration of reasonableness, but need not be decisive. If the claim for compensation is related to serious criminal acts, eliminating the liability or reducing it below the normal amount would require considerably more than in other cases. All in all, the Court in this case found that the aims of rehabilitation and resocialisation should not lead to a reduction of the young boy's obligation to pay compensation to the relatives, in the light of his brutal acts of killing two individuals. In addition, the compensation was seen as a way to hold the perpetrator accountable for what he had done.

As an example from another area, I find this decision interesting in that it uses the best interests of the child in interpreting the reasonableness criterion in the Compensation Act. The aims of rehabilitation and resocialisation are discussed based on CRC article 40. Although from a different article, these aims also serve to inform the best interests assessment and thus the assessment of reasonableness.

\subsection{Summing $U p$}

Although the best interests of the child have been examined and considered in all of these cases, the constitutionalisation of the obligation to take them into account as a primary consideration does not seem to have had a bearing on the Court's reasoning in the judgments above. The reason is partly that article 3(1) was already part of Norwegian legislation through the Human Rights Act; partly that best interests were already considered in practice by the ECtHR. As for child protection cases, the best interests of the child have since long been the decisive consideration according to the Norwegian Child Welfare Act. In the judgments no particular arguments are taken from section 104, thus it is hard to say that it has had any independent significance in Supreme Court practice. However, it is always mentioned, which at least underpins the importance of the best interests principle.

Impact on the Preparation of Legislation

\subsection{Introduction}

Legislative bodies are specifically mentioned in article 3 among those that are obliged to take children's best interests into account as a primary consideration. Moreover, General Comment No. 14 states that the requirements of article 3 apply at all stages of the adoption of laws, policies, budgets etc. concerning 
children in general or as a specific group. ${ }^{56}$ Article 3 is not only relevant to an individual child, but to children in general or a certain group of children. All kinds of general implementation measures need to consider the best interests of the child. Regarding legislation, the general comment further states:

The right of the child to have his or her best interests assessed and taken as a primary consideration should be explicitly included in all relevant legislation, not only in laws that specifically concern children. ${ }^{57}$

It is easier to remember to do an assessment of the best interests of the child when preparing legislation with 'child' in the title, but it is just as important to include it for legislation that may be applied to children in other areas.

Best interests being included in the Constitution means a strengthened obligation on legislative authorities to take them into account in developing new legislation or law amendments. ${ }^{58}$ As stated by the Law Commission, including best interests in the Constitution makes the principle more visible, ${ }^{59}$ thus making it easier to remember and feel obliged to include. Below I have looked into some documents that have led or may lead to changes in the legislation to see whether any influence of the constitutional provision is visible. The laws or areas chosen are the Immigration Act, the Commission on Violence against Children, the proposal of a new Child Welfare Act and the proposed new Criminal Procedures Act, The question here is not whether a consideration of best interests is actually included in a law proposal, but whether it seems to make a difference that the obligation, since 2014, follows from the Consitution, not only from the incorporated CRC.

\subsection{The Immigration Act}

In 2015 and 2016 amendments to the Immigration Act were made in order to introduce a number of restrictive measures. ${ }^{60}$ In the preparatory works of both amendments children's best interests were considered.

With regard to taking asylum-seekers into police custody, the relevant provision in the Immigration Act was extended to certain asylum seekers who would

56 General Comment No. 14 (n 6) para 10.

57 General Comment No. 14 (n 6) para 31.

58 Bendiksen and Haugli (n 39) 56.

59 Dokument 16 (n 3 ) 32.5.1.

6o Act 20 Nov 2015 No. 94 amending the Immigration Act (restrictive measures) (endringer $i$ utlendingsloven, innstramninger), Act 17 June 2016 No. $5^{8}$ (restrictive measures II) (endringer i utlendingsloven, innstramninger II). 
most probably not have their applications processed (Section $106 \mathrm{~g}$ ). The aim of taking them into custody would be to ensure that they would not disappear and to facilitate a quick return. ${ }^{61}$ Unaccompanied minors and families with children, however, were explicitly exempted from this extension of the authority with the reasoning that even without an explicit exception it would hardly ever be allowed to take them into police custody. In that regard, somewhat surprisingly, reference was only made to provisions in the Immigration Act and the Criminal Procedures Act, not to human rights or the Constitution. ${ }^{62}$

The Bill concerning the second round of restrictive measures in the immigration context, on the other hand, refers to human rights and constitutional obligations for each of the proposed amendments. One of the proposals was to widen the mandate to give children only a provisional residence permit until the age of 18 . Reaching that age, the child would have to apply again. Many of the commenting bodies in the written hearing emphasised that the proposal was contrary to children's rights, including article $3{ }^{63}$ In spite of these objections, the Ministry in the Bill considered the proposal to be in line with Norway's obligations, since article 3 only required that the best interests of the child have been considered and weighed against other relevant considerations in a reliable manner. This did not imply that the child's best interests would necessarily be decisive. ${ }^{64}$ Best interests had to be given great weight by the authorities, including the legislator, without dictating a certain outcome. Other considerations might be so weighty that they be prioritised. ${ }^{65}$ The considerations weighing more heavily were, as usual in this area, those of immigration regulation, including providing disincentives to families to prevent them from sending a child alone on such a dangerous journey. Several of the commenting bodies disagreed with the Ministry's description of the facts in this respect, including governmental agencies. ${ }^{66}$

With reference to the constitutional provision in this regard, the Ministry explicitly said:

The Ministry presumes that section 104 second subsection of the Constitution should be interpreted in the light of the corresponding provision

\footnotetext{
61 Prop. 16 L (2015-2016) Amendments to the Immigration Act (restrictions) (endringer $i$ utlendingsloven mv., innstramninger), section 6.3.1, 18 .

62 Prop. $16 \mathrm{~L}$ (n 61), section 6.3.1, 19.

63 Prop. 9o L (2015-2016) Amendments to the Immigration Act (restrictions II) (endringer i utlendingsloven mv., innstramninger II), section 6.5.4.

64 Prop. 9o L (n 63), section 6.5.5, 72.

65 Prop. 9o L (n 63), chapter 4, 21.

66 Prop. go L (n 63), section 6.5.
} 
in the CRC article 3, ref. Rt. 2015 p. 93, and that the provision does not make any additional demands of the legislator than what already follows from the CRC. ${ }^{67}$

It is interesting that the Ministry comments on the relationship between article 3 and section 104, and they may be right in saying the latter makes no additional demands. Yet, seen in relation to the emphasis on best interests not necessarily being decisive, the Ministry reduces the importance not only of article 3 but also of the Constitution section 104(2). Of course, it is correct that 'a primary' consideration means that other considerations may weigh more heavily, but not without a proper examination of the effects on children of the proposed rule, including how the uncertainty of their situation affects their development. In line with children's right to development under article 6, the ultimate purpose of considering the child's best interests should be to ensure the full and effective enjoyment of the rights recognised in the Convention and the holistic development of the child. ${ }^{68}$ Such an examination of the effects on children's development had not been undertaken.

\subsection{The Commission on Violence against Children}

In its report from 2017 on serious cases of violence against children, called Failure and Deceit, ${ }^{69}$ the government appointed Commission on Violence Against Children (the VAC Commission) pays great attention to the principle of the best interests of the child. It states the following:

The constitutional provision and the incorporation of the CRC through the Human Rights Act implies that legislation which does not explicitly mention the principle of the child's best interests shall be interpreted so as to include it. ${ }^{70}$

The VAC Commission points out that the best interest principle is not explicitly included in a wide range of legislation. Apart from in the area of children and parents - the Children and Parents Act, the Adoption Act and the Child Welfare Act - it is included in the Biotechnology Act and the Immigration

67 Prop. 9o L (n 63) section 6.5.5, 73 (author's translation).

68 General Comment No. 14 (n 6) para 51.

69 NOU 2017: 12 Svikt og svik - Gjennomgang av saker hvor barn har vært utsatt for vold, seksuelle overgrep og omsorgssvikt (Barnevoldsutvalget) <https://www.regjeringen.no/ no/dokumenter/nou-2017-12/id2558211/ $\geq$ accessed 2 April 2019. 
Act. ${ }^{71}$ Therefore, the Commission asked the author of this chapter to write a report on how the best interests of the child could be included in legislation in all relevant areas. My report appears as an attachment to the Commission's report. ${ }^{72}$ Seen in the light of the topic of this chapter, my report seems to take for granted that including the provision in the Constitution does not add much to the obligations that already followed from CRC article 3, at least it is not discussed. What the report does say is that the best interests of the child have been raised to a higher level within the sources of law.

The Commission itself in its deliberations recommends that the best interest's principle be explicitly included in various pieces of legislation regulating different sectors of society. Interestingly, they say that this should happen not because of, but in spite of, the incorporated article 3 and the Constitution section 104. Since, according to these provisions, the principle is already part of Norwegian legislation, it should not be necessary to include it in other statutes regulating specific areas. Nevertheless, the Commission made this recommendation to make the principle more visible and thus increase the attention to it, as well as to clarify its meaning in certain contexts. The aims would be to improve co-ordination between sectors and to stimulate the various sectors to have a more active role in their work to prevent violence and identify and follow up children exposed to violence. ${ }^{73}$

\subsection{Proposal for New Child Welfare Act}

The Commission preparing the new Child Welfare Act mentions that section 104(2) provides the best interest's principle with constitutional status and that the provision is modelled on CRC article $3(1)$ and the EU Charter article 24(2). The report then discusses the interpretation of article 3 . Thus, article 3 and section 104 are discussed together, and the report does not indicate any additional value of including it in the Constitution, apart from increased status as mentioned. ${ }^{74}$

Attached to the Commission's report is a separate report on child welfare and human rights. ${ }^{75}$ This report discusses the difference between the formulation

71 Act 8 April 1981 No. 8 relating to children and parents (Children and Parents Act), Act 16 June 2017 No. 48 relating to adoption (Adoption Act), Act 17 July 1992 relating to child welfare services (Child Welfare Act), Act 5 December 2003 No. 100 relating to the application of biotechnology in human medicine, etc. (Biotechnology Act), Act 15 May 2008 No. 35 relating to the admission of foreign nationals into the realm and their stay here (Immigration Act).

72 Kirsten Sandberg, Barnets beste i lovgivningen: Betenkning til Barnevoldsutvalget, 21 December 2016.

73 NOU 2017:12, section 13.4.2.

74 NOU 2016: 16 Ny barnevernslov - Sikring av barnets rett til omsorg og beskyttelse.

75 NOU 2016: 16, attachment 4, Child welfare and human rights. 
in the constitution, which only demands that best interests be 'a primary consideration' and the present Child Welfare Act stating that they shall have 'decisive weight'. The report refers to the preparatory works of the constitutional provision saying that best interests imply a proportionality consideration and that the weight of the child's best interests depends on how strongly affected the child is and how serious the decision is for the child. Since child protection cases are so important for the child, the report concludes that section 104(2) may possibly require that the best interests of the child be decisive in child protection cases, unless the case affects the child insignificantly. In any case, as the report states, there is nothing to prevent the legislator from going further than what the Constitution requires. This would also be in line with the jurisprudence of the ECtHR requiring that in such cases the best interests must come before all other considerations, not just be 'a' primary consideration. The ECtHR has also used the term 'paramount.' ${ }^{76}$

\subsection{Proposal for a New Criminal Procedure Act}

The Law Commission appointed to propose a new Criminal Procedure Act in 2016 submitted a report of around 700 pages. ${ }^{77}$ The report, which is an impressive piece of work, does not mention the Convention on the Rights of the Child, except in relation to detention of children before and after the incorporation of the Convention in 2003. Nor does it mention section 104 of the Constitution. Regarding human rights, it mainly concentrates on the European Convention on Human Rights. There should have been a reference to the CRC in relation to children in conflict with the law, at least article 37 on deprivation of liberty and article 40 on procedural safeguards, but also the best interests of the child and the right of the child to be heard. The latter is of interest in respect of children as victims or witnesses as well. The lack of such references and discussions is concerning and seems to suggest an indifference to the situation of children in conflict with the law and their rights.

\section{$6 \quad$ Concluding Remarks}

Law proposals to a varying degree refer to the constitutionalisation of the best interests of the child. The two reports which explicitly comment on the

76 Neulinger and Shuruk v Switzerland, App no 41615/07 (Grand Chamber 6 July 2010), para. 135, R. and H. v. the UK, App no 35348/o6 (31 May 2011), para 73 . 
significance of section 104(2) take different positions. The Ministry preparing the amendments to the Immigration Act seems to reduce the importance of the provision by saying that it makes no demands in addition to those already following from article $3(1)$, while, at the same time, stressing that best interests need not be decisive. The report on human rights attached to the Child Welfare Act proposal takes the provision more seriously in suggesting that in light of the proportionality aspects of section 104(2), the legislator may actually have an obligation to make the best interests of the child the decisive factor in child protection cases. Unsurprisingly, the best interests of the child is thus given a stronger position in child protection cases than in immigration cases. Nonetheless, the fact that immigration is a more politicially sensitive area with allegedly strong considerations pointing in the opposite direction, does not justify downplaying the best interests of the child and their constitutionalisation as done by the Ministry.

The Supreme Court in its case law often mentions section 104(2) together with CRC article 3(1) but apparently with no added value. One exception worth noticing is the Maria judgment in early $2015,{ }^{78}$ making more active use of section 104. Even if the majority in the plenary judgment later that year ${ }^{79}$ deprived section 104(2) of any independent significance, the weight of that statement is reduced by its being an obiter dictum without relevance to the case in question. In its future practice the Supreme Court should take the opportunity to emphasise the importance of the constitutionalisation by demanding more of the examination of the child's best interests undertaken by administrative authorities, as well as its weight in decisionmaking, thus strengthening the obligation to take children and their interests seriously.

In this chapter, I have focused on case law and preparation of legislation. Yet, the obligation to make the best interests of the child a primary consideration has a much wider scope. All general measures undertaken by the central, regional and local authorities shall take the best interests of children into account, such as budgeting processes, plans and decisons in all areas - transportation, the environment, health, education, leisure etc. Also, in the everyday life of the child, all actions shall have the best interests of the child as a primary consideration, in regard to play, sports, family life etc.

The prominent status that the best interests of the child have achieved by being included in the Constitution reinforces the right of children to have their

$78 \quad$ Rt 2015 p 93 (see 3.2 above).

79 Rt 2015 p 1388 (see 3.3.1 above). 
best interests taken into account and the obligation of the State and other actors to do so. Through a more active attitude to the constitutionalisation, the courts and the law-makers, as well as other actors, should emphasise in practice the added value that the higher status has provided.

\section{References}

Bendiksen L and Haugli T, Sentrale emner $i$ barneretten (3rd ed, Universitetsforlaget 2018).

Bårdsen A, 'Norges Høyesterett og «barnets beste» som konvensjonsforpliktelse og grunnlovsnorm' in Magnus Matningsdal, Jens Edvin A Skoghøy and Toril Marie Øie (eds), Rettsavklaring og rettsutvikling: Festskrift til Tore Schei (Universitetsforlaget 2016).

Dokument 16 (2011-2012) Rapport til Stortingets presidentskap fra Menneskerettighetsutvalget om menneskerettigheter i Grunnloven (9 December 2011).

European Convention on Human Rights, Convention for the Protection of Human Rights and Fundamental Freedoms, 1950.

Jerkø M, 'Skal ikke «barnets beste» leses bokstavelig? - En kritikk av HR-2017-2015-A "Jakob-saken" (2018) 57(2) Lov og Rett 112.

NOU 2016: $16 \mathrm{Ny}$ barnevernslov - Sikring av barnets rett til omsorg og beskyttelse (dato Måned år).

NOU 2016: 24 Ny straffeprosesslov (dato Måned år).

NOU 2017: 12 Svikt og svik - Gjennomgang av saker hvor barn har vært utsatt for vold, seksuelle overgrep og omsorgssvikt (22 June 2017).

Prop. 16 L (2015-2016), Amendments to the Immigration Act (restrictions) (endringer $i$ utlendingsloven $m v$., innstramninger).

Prop. 9o L (2015-2016), Amendments to the Immigration Act (restrictions II) (endringer i utlendingsloven mv., innstramninger II).

Sandberg K, 'Barnets beste som rettighet', in Ingunn Ikdahl and Vibeke Blaker Strand (eds), Rettigheter i velferdsstaten: Begreper, trender, teorier (Gyldendal Akademisk 2015).

Sandberg K, Barnets beste i lovgivningen: Betenkning til Barnevoldsutvalget, 21 December 2016.

Skjørten K and Sandberg K, 'Children's Participation in Family Law Proceedings' in Malcolm Langford, Marit Skivenes and Karl Harald Søvig (eds), Children's Rights in Norway: An implementation Paradox? (Universitetsforlaget 2019).

Stang EG, 'Grunnloven § 104 - en styrking av barns rettsvern?' in Geir Kjell Andersland (ed), De Castbergske barnelover 1915-2015 (Universitetsforlaget 2015). 
UN Committee on the Rights of the Child, General Comment No. 12: The right of the child to be heard (20 July 2009) CRC/C/GC/12.

UN Committee on the Rights of the Child, General Comment No. 14 on the right of the child to have his or her best interests taken as a primary consideration (art. 3, para. 1) (29 May 2013) CRC/C/GC/14.

Aasen HS, 'Grunnloven § 104 og barnets beste: Høyesterett viser vei' (2015) 3 Tidsskrift for familierett, arverett og barnevernrettslige spørsmål 197-201. 